\title{
Will the real Tunisian Opposition please stand up? Opposition Coordination Failures under Authoritarian Constraints
}

\author{
Rikke Hostrup Haugbølle ${ }^{1}$ \\ Department of Cross Cultural and Regional Studies, University of Copenhagen \\ E-mail: rikhostrup@hum.ku.dk
}

\author{
Francesco Cavatorta, School of Law and Government, Dublin City University \\ E-mail: Francesco.cavatorta@dcu.ie
}

\begin{abstract}
This article examines the reasons behind the failure of Tunisia's opposition to forge effective coordination and collaborative links during the Ben Ali's regime, focusing specifically on the inability and unwillingness of political parties to act in concert in order to challenge Ben Ali's authoritarian rule. Focussing on two attempts at opposition coordination in the 2000s (Rencontre Démocratique and 18 October Collectif), it demonstrates that a number of interconnected explanations are at the heart of this failure, which range from ideological differences and strategic divergence to personal rivalries amongst opposition leaders. The key contention of the article is that divisions within the political opposition were as important as regime repression in sustaining the Ben Ali regime for over 20 years in power. In addition, the article contends that these intra-opposition divisions and past coordination failures explain the absence of political parties at the helm of the 2011 uprising.
\end{abstract}

Key Words: opposition parties, cross-ideological cooperation, coordination failures, Rencontre Démocratique, Collectif

\section{Introduction}

The popular uprisings that swept across the Middle East and North Africa (MENA) in late 2010 and early 2011 have caught most scholars and policy-makers by surprise. ${ }^{2}$ Indeed, over the past few years, mainstream scholarship on Middle East politics has tended to emphasise (and explain) the stability of authoritarian regimes in the region and their ability to introduce a number of seemingly

\footnotetext{
${ }^{1}$ The authors are grateful to the Panos Institute in Paris for its financial support in conducting research in Tunisia. We wish to thank all those Tunisians who gave us their time. Francesco Cavatorta is very grateful to Paul Aarts, Kawa Hassan, Reinoud Leenders, Salam Kawakibi and Juliette Verhoeven for the very fruitful discussions on opposition dynamics in the Arab world in the context of the HIVOS Knowledge Programme based at the University of Amsterdam. Rikke Haugbølle is grateful to Khaled Ben Brahim for the invaluable exchange of ideas. Finally, we would like to acknowledge the very useful comments received by Hendrik Kraetzschmar and the anonymous referees. An earlier version of this paper was presented at the Annual Conference of the British Society for Middle East Studies (BRISMES) held at the University of Exeter, 26-29 July, 2011.

2 D. Byman, 'Why Mideast Tumult Caught Scholars by Surprise', The Chronicle of Higher Education, (February 13, 2011). Available at: www.chronicle.com (accessed on February 13, 2011).
} 
liberalising reforms, without bringing about real democratic change. ${ }^{3}$ Whilst at first glance, this academic focus on authoritarian resilience might be in direct contradiction with the 'revolutionary' developments of early 2011, at a closer inspection analyses of how authoritarianism in the region operates and what kind of dynamics it creates in opposition circles are still relevant to our understanding of how politics will develop in the Arab world. Whatever the outcome of the so called 'Arab Spring', future political and institutional arrangements will be derived through path dependency from the relations and trends in place before the 'Spring. ${ }^{4}$ In addition, the enthusiasm with which 'transitologist' commentators and scholars such as Kaldor ${ }^{5}$ interpreted events in both Tunisia and Egypt - proclaiming a new dawn of democracy in both countries - should be moderated, as the outcome of the uprisings is still uncertain. As Ottaway rightly remarks, for now 'the presidents have left, the regimes are still in place. ${ }^{\prime 6}$

It is true that such genuine and widespread actions for political change have not occurred in decades in the region and that they might as yet result in a radical political transformation and even democratisation of the political system, but this is by no means a pre-determined outcome. ${ }^{7}$ Furthermore, the main agents of this revolutionary moment in the MENA region are not to be found in the "usual suspects" ${ }^{8}$ within the political opposition parties or in civil society. This constitutes the most interesting aspect of these popular uprisings, and part of the explanation as to why this has been the case has to do with the failure of traditional opposition parties and movements to effectively coordinate over the last two decades in order to challenge the regimes in place. In fact organised political and social movements seemed to lag behind, playing catch-up with actors that are very loosely if at all organised into formal groups. The protests were organised largely through new social media and on the streets with the masses playing a significant role rather than in formal institutional settings. As Béchir Ben Yahmed indicates, when writing on Tunisia, 'no party, no

\footnotetext{
${ }^{3}$ See for instance Lisa Anderson, 'Searching where the lights shines. Studying democratization in the Middle East,' Annual Review of Political Science, 9 (2006), pp. 189-214 and Steven Heydemann, 'Upgrading authoritarianism in the Arab world,' The Brookings Institution, Analysis Paper, 13 (2007), pp. 1-37.

${ }^{4}$ The authors are indebted to Steven Heydemann for pointing out that the concept of path dependency could be applied in this context.

${ }^{5}$ M. Kaldor, 'Civil society in 1989 and 2011', (February 7, 2011). Available at: http://www.opendemocracy.net/marykaldor/civil-society-in-1989-and-2011. Accessed on February 7, 2011.

${ }^{6}$ M. Ottaway, 'The Presidents left, the regimes are still there', Carnegie Endowment (February 14, 2011). Available at: http://carnegieendowment.org/publications/?fa=42627. Accessed on February 14, 2011.

7 See G. Friedman, 'Egypt: the distance between enthusiasm and reality', Stratford Weekly (February 13, 2011). Available at: http://www.stratfor.com/weekly/20110213-egypt-distance-between-enthusiasm-and-reality Accessed on February 13, 2011.

${ }^{8}$ The authors are grateful to Kawa Hassan and Paul Aarts for coming up with the term in this context.
} 
union, no politician gave the impetus for this popular uprising nor were they in any way involved, ${ }^{9}$ indicating that traditional political actors, whether in power or in opposition, were as surprised as the international community by the events. Such a situation points to an interesting paradox in the literature on authoritarian resilience, which had correctly identified the weakness of formal opposition parties and movements, whether legal or illegal, while failing, with the exception of a few ${ }^{10}$ to note the revolutionary potential of the Arab street, particularly at a time of profound socioeconomic crisis.

The crucial absence of established opposition political parties at the helm of the protests confirms the findings of studies that pointed to their weakness and indicates also the continued failure of different forms of cooperation, be they formal alliances or looser reform coalitions. For some time the literature on political parties in the Arab world had emphasised the significance of cooperation between opposition parties in challenging authoritarian rule, focusing specifically on cross-ideological cooperation between Islamists and leftist parties. ${ }^{11}$ In this article, we question the assumption of the importance of cross-ideological cooperation between opposition forces in so far as it has not proven to be durable, solid and effective in bringing about radical change, as the case of Tunisia highlights. When change arrived, as it did in Tunisia with the ouster of President Ben Ali, traditional opposition parties were caught off guard. Thus, in this contribution we argue that it is precisely the weakness/absence of cross-party cooperation that is a crucial aspect of how the events of early 2011 unfolded. We will look specifically at what we term 'coordination failures' between opposition parties. This does not mean that efforts at cooperation did not take place; quite the opposite is true, as a number of efforts were made to bring about such cooperation. In the Tunisian case, Martinez Fuentes examined ten instances of cross-party cooperation between 2004 and 2009, ranging from formal electoral alliances to looser reform coalitions with no electoral objectives. ${ }^{12}$ These efforts testify to the realisation among opposition movements and parties that cooperation was indeed of primary importance, if the challenge to the authoritarian regime was to be strong. However, most of these attempts should be deemed ultimately unsuccessful, as they proved to be short-lived and prone to rapid collapse.

\footnotetext{
${ }^{9}$ B. Ben Yahmed, 'Jours de victoire...', La Jeune Afrique, No. 2610, (16-22 January 2011), p. 4. The same point is made by H. Ben Abdallah El Alaoui, 'Tunisie, les éclaireurs', Le Monde Diplomatique, No. 683, (February 2011 ), p. 1.

${ }^{10}$ See for instance L. Sadiki, 'Towards Arab Liberal Governance: from the Democracy of the Bread to the Democracy of the Vote', Third World Quarterly, 18 (1997), pp. 127-148.

${ }^{11}$ For a comprehensive account of cross-ideological cooperation in the Arab world see J. Clark, 'Threats, Structures and Resources,' Comparative Politics, 43 (2010), pp. 101-120.

12 See G. Martinez Fuentes, 'El Islam politico Tunecino. Conflicto y coopearcion electoral en los comicios presidenciales de 2004 y 2009', Revista CIDOB d'Afers Internacionals, No. 93/94 (2011), pp. 89-109.
} 
Nevertheless, there are two specific instances of cross-party cooperation that stand out among the many such efforts in Tunisia, and it is on these two that this article focuses its empirical attention. These are Rencontre Démocratique and, more importantly, the 18 October Collectif, both of which were formed in the mid-2000s. There are a number of reasons that explain the focus on these two cooperation efforts. First of all, they were more extensive and durable than previous ones, with the initiative of the Collectif lasting for five years. Second, Rencontre Démocratique is representative of efforts at coordination made by parties that wished to 'play' within the rules of the game, while the Collectif is representative of coalitions whose members were anti-systemic and challenged the Tunisian political system as a whole. Third, Rencontre Démocratique was created to be an electoral alliance, while the Collectif was more of a front with the objective of providing citizens with a vision of a new Tunisia built on the shared values of democracy and human rights. While they deserve more attention than other short-lived and poorly coordinated initiatives such as the Initiative Nationale pour la Démocratie et le Progrès ${ }^{13}$ or Coordination Démocratique ${ }^{14}$ it is important to note that neither Rencontre and the Collectif succeeded where the others failed, that is in providing a serious challenge to the Ben Ali regime.

Taking this observation as its point of departure, this article explores the dynamics of the Tunisian opposition under the Ben Ali presidency (1987-2011), its relation to the regime and past efforts at building effective cross-party coalitions to press the government for liberalising reforms. It is the aim of this analysis to demonstrate that no strong and unified opposition existed during the Ben Ali era, which could have successfully challenged the foundations of the authoritarian government. The main reasons for this not only include the regime's skilful use of co-optation and repression, as Hibou or Martinez Fuentes indicated, ${ }^{15}$ but, crucially, the profound ideological, personal and strategic divisions extant among the country's opposition parties (both legal and outlawed). This challenges the notion emerging from other studies on other Arab countries that rapprochement between opposition parties is a crucial component of political change.

As shall be discussed below, these divisions had two important consequences for the political process in Tunisia, past and present. First, they enabled the Ben Ali regime to govern

\footnotetext{
${ }^{13}$ The INDP was an electoral alliance between three left -wing parties (Ettajdid, the Socialist party of the Left and the Parti du Travail Patriotique et Démocratique) that had decided to support Ahmed Brahim as a presidential candidate in 2009. It was created just before the election and vanished after it.

${ }^{14}$ It was an initiative between four parties aimed at defending the rights of political prisoners. It was very much an $\mathrm{ad}$ hoc alliance without further objectives than supporting freedom of speech.

${ }^{15}$ See B. Hibou, La Force del'Obéissance, Paris : La Découverte, 2006. and G. Martinez Fuentes, 'Divisive electoral policies within authoritarian elections: the Tunisian casuistry (1989-2009)', Journal of North African Studies, 15 (2010), pp. 521-534.
} 
without any serious threat from the political opposition and allowed it to rule without systematically resorting to widespread repression until leaderless mass protests triggered a radical change in 2011. Second, divisions among the opposition and a history of coordination failures also make the management of post-revolutionary Tunisia more difficult, as parties and their leaders jockey for position rather than uniting behind a clear project of institutional renewal. The previous ideological, personal and strategic divisions that had characterised their relations have re-emerged strongly, notably in the attempted marginalisation of the Islamist party Al-Nahda by the secular left.

This subsequent study of opposition dynamics in Tunisia is divided into two sections. A first section reviews the extant theoretical literature on opposition cooperation (involving both legal and illegal opposition forces) in electoral authoritarian regimes and its capacity to push for liberalising reforms from within the confines of the existing political order. Section two then explores the nature and types of opposition politics in Tunisia during the Ben Ali era and examines in detail the reasons why the traditional opposition parties failed to build and sustain solid coordination and collaborative forms of organisation, such as the formation of viable electoral alliances or broader based reform coalitions. This article discusses in detail the cases of Rencontre Démocratique and the Collectif, the most important and extensive attempts at cross-party coordination to date.

\section{Opposition cooperation under electoral authoritarianism: a theoretical discussion}

Traditional democratization theory postulates that all legitimate opposition actors ${ }^{16}$ by definition see authoritarian rule as the main problem that needs to be removed in order for them to have the possibility of running the country according to their own ideological beliefs and policy preferences. Such opposition actors can exist both inside and outside formal institutions and can be legal or illegal entities, but are all believed to share the same 'distaste' for the corrupt and unaccountable elites ruling the country and a desire for meaningful political change. Although difficult to trigger in entrenched authoritarian settings, this change, according to some scholars, is best achieved if and when the opposition is united behind a common set of reform demands and pursues a collective strategy of undermining the predominance of the incumbent regime. Such opposition unity can be beneficial in two regards. First it may help diminish the operational costs of individual (often

\footnotetext{
${ }^{16}$ The definition of political opposition we utilise is from Albrecht and is the following: 'an institution located within a political system but outside of the realm of governance that has decisive organisational capacities and engages in competitive interactions with the incumbents of a political regime based on a minimum degree of mutual acceptance.' The definition can be found in H. Albrecht, 'Introduction - Contentious politics, political opposition, and authoritarianism' in H. Albrecht (ed.) Contentious politics in the Middle East. Political Opposition under Authoritarianism, (Florida: Florida University Press, 2010), p. 3.
} 
resource-poor) opposition parties and, second, it carries the potential of increasing the capacity for (electoral) mobilisation. A united front, for instance, would enable the opposition to pool its support base; an electoral alliance would reduce the costs (human and financial) of running candidates and could have wider popular appeal; and a common reform agenda could present a viable alternative to the incumbent regime and thus attract the attention of a broader segment of society. ${ }^{17}$

More recent scholarship on opposition coordination and collaboration in the MENA region has also highlighted both the occurrence and the significance of cross-party alliance-building, focusing specifically on patterns of cross-ideological co-operation. Schwedler ${ }^{18}$ and Browers ${ }^{19}$ on Yemen, Clark ${ }^{20}$ on Jordan and Abdelrahman ${ }^{21}$ on Egypt all emphasise the relevance of crossideological cooperation, with Browers arguing that there are even 'antecedents of contemporary cross-ideological coordination among various oppositional elements that have traditionally opposed each other.' 22 She further argues that this challenges the idea that the formalisation of crossideological cooperation ' $\operatorname{lack}[\mathrm{s}]$ thinking, $\operatorname{lack}[\mathrm{s}]$ constrictive political programmes, and $\operatorname{lack}[\mathrm{s}]$ political...significance. ${ }^{23}$ The importance of these efforts should not be denied a priori, but there are two elements that might moderate the enthusiasm for such cooperation. First of all, crossideological cooperation might be undermined by personal rivalries and/or strategic differences that affect relations between parties and their leaders, thus limiting the capacity to build a broad based opposition front against the authoritarian incumbent even in the presence of ideological moderation. As Wegner and Pellicer highlight in their contribution on Morocco in this special issue, when ideology is not an explanatory variable for the absence of coordination, there might exist other factors at play such as 'asymmetry in electoral strength.' Second, there is also evidence that opposition parties might perform, willingly or indirectly, a radically different role to the one envisaged in the democratization literature and to the one that studies on inter -party collaboration in the MENA suggest. Thus, they can, paradoxically, function as pillars of authoritarian survival

\footnotetext{
17 N. Van de Walle, 'Tipping Games: When Do Opposition Parties Coalesce?,' in A. Schedler (ed.) Electoral Authoritarianism: The Dynamics of Unfree Competition (Boulder: Lynne Rienner, 2006), pp. 77-92. See also, H. Kraetzschmar, 'Opposition Cooperation in Electoral Autocracies: the united National front for Change in Egypt's 2005 Parliamentary Elections' in H. Albrecht (ed.) Contentious politics in the Middle East. Political Opposition under Authoritarianism, (Florida: Florida University Press, 2010).

${ }^{18}$ J. Schwedler, Faith in Moderation (Cambridge: Cambridge University Press, 2006).

${ }^{19}$ M. Browers, 'Origins and Architects of Yemen's Joint Meeting Press', International Journal of Middle East Studies, 39 (2007), pp. 565-586.

${ }^{20}$ J. Clark, 'The Conditions of Islamist Moderation: Unpacking Cross-Ideological Cooperation in Jordan', International Journal of Middle East Studies, Vol. 38 (2006), pp. 539-560.

${ }^{21}$ M. Abdelrahman, 'With the Islamsits? - Sometimes. With the State? - Never! Cooperation between the Left and Islamists in Egypt', British Journal of Middle Eastern Studies, 36 (2009), pp. 37-54.

${ }^{22}$ M. Browers, Political Ideology in the Arab World (Cambridge: Cambridge University Press, 2009), 175.

${ }^{23}$ Ibid., p. 175.
} 
itself. $^{24}$ This is for two main reasons. First of all, a number of opposition parties and movements have been traditionally co-opted by the ruling elites, maintaining therefore only virtual autonomy. Accepting to be co-opted is due to multiple reasons, including the perceived/real threat of repression or the genuine belief that preferred policy choices can be better pursued by cooperating with the authoritarian ruler/regime than by opposing it. ${ }^{25}$ More material motives can also enter the calculation regarding the acceptance of co-optation. Such benefits might include legalisation, access to public funding, or guaranteed seats in parliament. ${ }^{26}$ The second reason for accepting co-optation is that there might be the legitimate expectation that participating to institutional life, even under tutelage, might constitute relevant training and experience if and when the authoritarian structures vanish.

From the regime's point of view, attempting to co-opt the country's opposition parties is beneficial in two regards. First, it enables the regime to control what opposition actors do while at the same time being able to present a façade of pluralism to the international community. Second, Islamist and secular/leftist opposition parties/movements in the MENA region tend to subscribe to radically opposed ideologies and these divisions, which might also include strategic and personal rivalries, can be manipulated for successful 'divide and conquer' tactics. The contention here is that while there have been examples of cross-ideological co-operation between these two sets of opposition forces and a convergence towards a shared definition of democratic accountability, mutual suspicions still remain and make successful opposition co-operation between such ideologically diverse actors very difficult. This has led some secular opposition parties to side, at times, with the regime rather than with Islamist movements and vice versa. In addition, divisions have also emerged in the same ideological camp with regard to the choice of cooperating with ideological rivals, further fragmenting opposition politics, as for instance the rifts within the Moroccan left over the issue of cooperation with the Islamist group Justice and Charity demonstrate. $^{27}$

\footnotetext{
24 See for instance H. Albrecht, 'How Can Opposition Support Authoritarianism? Lessons from Egypt,' Democratization, 12 (2005), pp. 378-397.

${ }^{25}$ For a discussion on the dilemma between co-optation and marginalisation see F. Cavatorta, 'More than Repression; Strategies of Regime Survival. The Significance of Divide et Impera in Morocco', Journal of Contemporary African Studies, 25 (2007), pp. 187-203.

${ }^{26}$ For a discussion on the role of material benefits for parties accepting authoritarian regimes' terms for participation see E. Lust, 'Elections under Authoritarianism: Preliminary Lessons from Jordan', Democratization, 13 (2006), pp. 456471.

${ }^{27}$ E. Dalmasso and F. Cavatorta, 'The Emerging Power of Civil Society? The Human Rights Doctrine' in B. MaddyWeitzman and D. Zisenwine (eds.) Contemporary Morocco: State, Politics and Society under Mohammed VI, (Routledge, London, forthcoming 2012).
} 
Thus, following the post-democratization theoretical input, ${ }^{28}$ we postulate that self-defined political opposition needs not to be opposed to authoritarianism per se in so far as the authoritarian gatekeeper can also be a useful ally to combat the ideological and policy positions of rival opposition parties. It is possible therefore to hypothesise that sectors of the opposition might accept the 'current rules of the game', i.e. the parameters of authoritarian rule, and operate not to change the regime but to modify the structure of the public sphere. When this occurs, cross-party cooperation is rendered much more difficult as opponents can accuse each other of 'selling out' (for those who accept the rules of the game) and of 'extremism' (for those who refuse to accept to work with the regime). All this inevitably poisons the relations between parties and leaders whose main objective should be to unite to change the institutional structures they operate in. This connects to what Albrecht calls 'anti-incumbent and anti-policy opposition. ${ }^{29}$ What he means by this is that that a 'loyal' opposition opposes the incumbents or specific policies that the regime might implement, but does not oppose the rules of the game and therefore implicitly accepts the authoritarian nature of the system and plays within its limits, because there is a fear of a democratic chaos in which they might be the losers if the gatekeeper were to be removed. In addition to these types of opposition, there exists what have been termed 'anti-systemic forces', which are usually the target of relentless regime repression because they advocate a radical overhaul of the political system. The dynamics that these types of political opposition generate in Arab countries are an important explanatory variable for the resilience of authoritarianism, going beyond the exclusive reliance on overt and sustained repression that is often used to account for the persistence of authoritarian rule. ${ }^{30}$

Furthermore, and contrary to the literature on cross-ideological cooperation, we argue that such co-operation is over-emphasised and that profound differences still remain, affecting the way in which authoritarian rulers are confronted, the manner in which radical regime change might come about and where it would lead to. In order to explain how the Tunisian opposition was both unable to face down Ben Ali and be almost unaware of the societal rage against the regime and guide it, we hypothesise that it is critical to understand the divisions that exist between opposition parties and their failure to forge effective forms of cross-party cooperation. Similarly to other

\footnotetext{
28 For a discussion on post-democratization see M. Valbjørn and A. Bank, 'Examining the Post in PostDemocratization: The Future of Middle Eastern Political Rule through the Lenses of the Past', Middle East Critique, 19 (2010), pp. 183-200.

${ }^{29}$ Albrecht, Contentious politics in the Middle East, 2010, p. 7.

${ }^{30}$ E. Bellin, 'The Robustness of Authoritarianism in the Middle East', Comparative Politics, 36 (2004), pp. $139-157$.
} 
studies, ${ }^{31}$ we argue here that the most significant divisions within the opposition rest on ideological, strategic and personal conflicts and some of these divisions have not disappeared in the post-Ben Ali era. It is the failure of the opposition to generate unitary discourses and practices that partly explains the success of the 'divide et impera' strategies of the regime and account for their inability to 'read' the mood of Tunisian society, which had to resort to the 'street' to finally achieve some form of political change.

The next section will discuss the party politics dynamics that characterised the vast family of Tunisian opposition since the creation of the state to highlight the way in which coordination failures allowed the Ben Ali's regime to survive for three decades.

\section{The opposition landscape under Ben Ali: between ideological, strategic and personal rivalries}

Opposition politics always had a difficult time in Tunisia since independence, as the ruling party established by Bourguiba (1956-1987) and re-named and re-shaped under Ben Ali dominated the political landscape in a country with no democracy from $1956 .{ }^{32}$ Nevertheless, over time a number of opposition political parties managed to emerge. The most important of these include the Mouvement d'Unité Populaire (MUP), the Mouvement des Démocrates Socialistes (MDS), AlNahda (previously known as the Mouvement de la Tendence Islamique, MTI) and the Parti d'Unité Populaire (PUP). With the exception of the Islamist Al-Nahda, virtually all political parties belonging to the 'historical opposition' are, in one way or the other, off-springs of the original NeoDestour party, which was set up by Bourguiba in the 1930s and dominated political life until the departure of Ben Ali. ${ }^{33}$ As such they all share a vaguely socialist ideology; their main differences residing in questions of what form of socialism should be implemented. In addition, their history suggests that none of these parties were created in order to represent emerging social constituencies or new social groups, but were essentially the product of personal rivalries. Consequently a strong personality element has prevailed amongst leaders and members of Tunisia's opposition parties, inhibiting proper institutionalisation and making parties vehicles for self-promotion rather than transmission belts between society and the state. This 'personality' element had been thus noted in 1999:

\footnotetext{
${ }^{31}$ F. Cavatorta, 'Divided they Stand, Divided they Fail: Opposition Politics in Morocco', Democratization, 16 (2009), pp. 137-156.

${ }^{32}$ The Neo-Destour was the party that led Tunisia to independence. It was renamed Parti Socialiste Destourien (PSD) in 1964 and re-named again under Ben Ali as Rassemblement Constitutionel Démocratique (RCD).

${ }^{33}$ K. Perkins, A History of Modern Tunisia (Cambridge: Cambridge University Press, 2004.
} 
'(...) none of the opposition parties possesses effective leadership: instead, they are disorganised and internally divided - the production of personality clashes between powerhungry members. Moreover, the parties squabble among themselves, failing to achieve joint positions or action. The parties do not articulate clear policy programmes. The parties on the left are crippled because communism is incompatible with Islam, or because socialism has been discredited, or because Arab nationalism is passé. ${ }^{34}$

A genuine challenge to the dominant socialist and nationalist ideologies, that shaped the embryonic party politics of the country, emerged with the creation of an Islamist party named $A l$ Nahda in the late 1980s. Founded by Rashid Ghannouchi in 1981, Al-Nahda introduced a very different ideology of reference in the secular Tunisia that both Bourguiba and Ben Ali were intent on crafting, and has therefore been much more severely repressed during the Ben Ali's era than any other political movement/party in the country, with the exception of the Tunisian Party of Communist Workers (PCOT). ${ }^{35}$

Lastly, it should also be noted that during the Ben Ali era, a number of other opposition parties emerged, such as the Parti Démocrate Progressiste (PDP, founded by Nejib Chebbi in 1983 and legalised in 1988 when it was still named Rassemblement Socialiste Progressiste), the Congres pour la République (founded in 2001 by Moncef Marzouki but never legalised under Ben Ali) and Ettajdid, heir to the Tunisian Communist Party, founded and legalised in 1993. Thus, over time, the Tunisian political landscape changed and witnessed the arrival of a host of new political parties, all of which claimed to offer an alternative to the authoritarian status quo, yet most of them remained anchored to socialist or social-democratic principles with the real alternative to the political left being presented only by Al-Nahda. The rising number of political parties, however, did not significantly alter the authoritarian nature of the political system at the time, and their inability to coordinate effectively due to ideological, personal and strategic divisions partially explains the survival of authoritarianism for over five decades.

As mentioned above, since independence in 1956 and until the departure of Ben Ali in January 2011, Tunisia had only known two presidents - Bourguiba and Ben Ali - both of whom believed that they would remain in their posts for life and therefore built political structures to ensure precisely that. Both presidents headed a highly personalised political system, based largely around clientelist structures, but they nevertheless used formally autonomous institutions to govern the country, and their ruling party featured in this institutional design.

\footnotetext{
${ }^{34}$ M. Penner Angrist, 'Parties, Parliament and Political Dissent in Tunisia', Journal of North African Studies, 4(1999), pp. 89-104.

35 R. Basly, 'The Future of al-Nahda in Tunisia', Arab Reform Bulletin (April 20, 2011). Available at: http://www.carnegieendowment.org/arb/?fa=show\&article=43675. Accessed on April 27, 2011.
} 
Initially, the very history of opposition politics in Tunisia is bound up with ideological differences within the broad left. In 1973 the first Tunisian opposition party was created in exile by Ahmad Ben Saleh, a onetime close ally of Bourguiba within Neo-Destour, who objected to the abandonment of strict socialist economic policies on the part of the President. After spending some time in prison, Ben Saleh, who was accused of harbouring too rigorous socialist ambitions that undermined national unity, ${ }^{36}$ fled for Algeria where he set up the Mouvement d'Unité Populaire (MUP) to challenge the dominance of Bourguiba's ruling party. The creation of MUP, which was not legalised, was the outcome of a long and tense relationship between Ben Saleh and Bourguiba. Ben Saleh had much stronger socialist inclinations and as the leader of the General Union of the Tunisian Workers (UGTT) he sought the implementation of a clear socialist programme that he believed the Neo-Destour party should adopt. Bourguiba, however, was conscious of the problems that sticking to a strict socialist agenda might cause in the countryside for wealthy land-owners and as Perkins noted

'(...) after independence greatly divergent views about the nature of the independent state [emerged]. Particularly acute philosophical differences between the union and the party meant that tightening Neo-Destour control over the UGTT assumed an extremely high priority following independence. ${ }^{37}$

When this occurred a showdown between the two men became inevitable and Ben Saleh became an opposition figure. Due to its illegal status, the MUP was heavily repressed and the party split, with a faction moving on in 1979 to found the Parti d' Unité Populaire (PUP), which adopted a very similar ideological outlook to the MUP's. The PUP's leadership however adopted a proregime line, was legalised in 1983 and its party's leaders, first Mohamed Belhaj Amor and then Mohamed Bouchiha, ran in the presidential elections organised by Ben Ali in 1999, 2004 and 2009, providing the Tunisian regime with some of the 'pluralist' legitimacy it needed for external consumption.

When Ben Ali came to power in a palace coup against incumbent Bourguiba in November 1987, he promised to initiate democratic reforms and greater political pluralism. Following on his promise, he offered opposition parties a national pact, according to which they would refrain from destabilising the existing political order in exchange for the gradual introduction of liberalising

\footnotetext{
36 See E. Murphy, Economic and Political Change in Tunisia. From Bourguiba to Ben Ali (London: Palgrave Macmillan, 1999).

${ }^{37}$ Perkins, A History of Modern Tunisia, p. 134.
} 
reforms. In order to provide credibility for his political project, Ben Ali legalised a number of previously banned political parties including Chebbi's PDP and the Parti Social-Liberal (PSL). However, this 'democratic spring' in Ben Ali's Tunisia proved to be short lived, with the president reneging on his reform pledges once he had secured his own position at the helm of government. Nonetheless, despite ever increasing government repression, several opposition parties, including the PUP, continued to operate in the political and electoral arena, playing the role of a 'loyal' opposition. ${ }^{38}$ In a 2009 interview, the PUP leader Bouchiha argued strongly that 'the party's programme meets the expectations of citizens and that the party does not want to be negative all the time $^{39}$, indicating that political parties that constantly criticise what is wrong with the Tunisian political system are doing a disservice to what the President is attempting to do, which is the gradual introduction of democracy. The Tunisian newspaper Le Temps also reported that the Political Bureau of the PUP saw the participation of Bouchiha in the presidential elections of 2009 as 'the proof of the very positive political climate that exists today in Tunisia. ${ }^{40}$ Bouchiha and the PUP believed that participation in the political structures set up by Ben Ali was necessary to achieve some of the objectives of the party and his brand of modern socialism. Cooperation with the government was thus deemed more advantageous to the party's positions than being left at the margins of decision-making.

The path followed by the PUP is indicative of how the stark choice between co-optation and repression that Ben Ali offered to opposition parties undermined the possibility of strong coordination amongst the country's opposition. Indeed, those parties that accepted to play the game according to the rules of the regime, quickly lost credibility with opposition forces which had decided that such a compromise constituted in fact a 'sell-out' of democratic values and principles. It is interesting to note in this context, that the ripples of the choices made by opposition parties at the time can still be felt in the early post-Ben Ali era with the Mouvement des Démocrates Socialistes (MDS) being the target of particular vitriol.

The MDS, founded by Ahmad Mestiri in 1978 after he left the PSD and legalised in 1981, is another example of a political party created to challenge the regime that ended up as one of its main pillars when Ben Ali took over as president. Just like other political parties at the time, it signed the national pact proposed by Ben Ali in 1988. The MDS was at the time the strongest opposition party

\footnotetext{
${ }^{38}$ For a discussion of the Tunisian National Pact of 1988 see L. Anderson, 'Political Pacts, Liberalism and Democracy: the Tunisian National Pact of 1988', Government and Opposition, 26 (1991), pp. 244-260.

${ }^{39}$ The interview can be found at Le Temps: http://www.letemps.com.tn/article-32819-28082009.html. Accessed March $3,2011$.

${ }^{40}$ Ibid.
} 
and was believed to be a genuine contender for power. As Angrist (1999) underlines, 'the MDS's platform calls for multiparty competition, liberty of expression, improved human right practices, the augmentation of individual and group freedoms, and the separation of the ruling party's apparatus from that of the state. ${ }^{41}$ Similar to the MUP, the party, however, quickly split on the issue of its relations with the Ben Ali regime, with Mohamed Mouadda closely aligning himself with the President, particularly on the issue of anti-Islamist repression, whilst Mustapha Ben Jafaar moved on in 1994 to found the Forum Démocratique pour le Travail et les Libertés (FDTL), which took a more critical stance toward the regime and what it described as its authoritarian tendencies. ${ }^{42}$ The FDTL, a social-democratic party, was eventually legalised in 2007 in an attempt by the regime to render the 2009 presidential elections more credible. The alignment of the MDS to Ben Ali's positions occurred in the early 1990s. In 1994 the MDS supported Ben Ali's bid for re-election, in exchange of which the party was able to win 10 seats in parliament out of 163 . The same scenario was repeated in 1999 when the party officially supported Ben Ali's presidential election bid, for which it was this time rewarded with 16 seats in parliament out of $182 .{ }^{43}$ In 1995 , the MDS experienced further internal divisions when Mouadda criticised the regime and was jailed for it despite his previous support, with some members following Mouadda and others denouncing his new anti-regime stance. An internal battle ensued as to who really controlled the party.

Unlike most of its secular counterparts, Ghannouchi's Al-Nahda party never obtained legal status under the Bourguiba and Ben Ali regimes, and was only recently legalised by the transitional authorities in Tunisia in 2011. During the 1987/1988 period Ben Ali had invited Al-Nahda to join the other opposition parties in signing the national pact, and the Islamists did indeed sign up to the agreement. The party was allowed to run independent candidates in the 1989 legislative elections and according to many observers did very well. It is precisely this good performance that made Ben Ali renege on his promise of legalisation, particularly given the developing situation in Algeria at the same time. ${ }^{44}$ The Islamist challenge in Tunisia was met with harsh repression and the fear of Islamism became a powerful instrument that Ben Ali used to co-opt a number leftist parties and

\footnotetext{
${ }^{41}$ Penner Angrist, 'Parties, Parliament and Political Dissent'.

${ }^{42}$ See the September 25, 2009 interview by Le Monde's correspondent Florence Beaugé with Ben Jaafar available at http://www.lemonde.fr/afrique/article/2009/09/25/tunisie-1-opposant-mustapha-ben-jaafar-candidat-a-lapresidentielle_1245376_3212.html.

${ }^{43}$ A short summary of the elections results can be found on the official page of the United Nations Development Programme at http://www.pogar.org/countries/theme.aspx?t=3\&cid=20.

${ }^{44}$ In 1990, the Islamist party in Algeria scored an impressive victory in the local elections and the following year it won the legislative elections, indicating the strong support that Islamists had in North Africa. Rather than risking an Islamist take-over through the ballot box, the Algerian Army organised a coup, annulled the elections' results and banned the party. A civil war ensued and the violence emanating from Algeria affected the way in which other Arab leaders dealt with Political Islam.
} 
leaders who were equally afraid of $A l-N a h d a$ for the policies it might implement if in power, including the complete dismantling of even nominal democratic structures. ${ }^{45}$

Ben Ali's strategy from the beginning of his rule was the attempt to divide and conquer the opposition parties that had signed up to the national pact in 1988, playing specifically on the ideological differences and well-known strategic divergences that affected them. In this he was quite successful and the coordination failures that have plagued the Tunisian opposition ever since the 1990s can be traced to this period in Tunisian history. The reliance of Ben Ali on the repressive apparatus should not be underestimated as a cause of these coordination failures, but opposition parties contributed significantly to them due to their divergences. The most sensitive ideological division on which Ben Ali played during his reign was the one between secular parties and Islamists. There was for instance a strong ideological element linked to the issue of supporting a ban on Al-Nahda. The small leftist party Ettajdid and the Democratic Communist Party, for instance, were ideologically so opposed to Al-Nahda, going as far as to denying them the democratic right to participate because of the belief that political Islam is inherently contrary to democracy. Other parties, including the PDP, argued by contrast that legalisation was a right for $\mathrm{Al}$ Nahda no matter how unpalatable the political positions of Islamists might be. In the end, while not all secular parties were necessarily anti-Islamist - with some insisting that all parties of the national pact be granted legal status, thus including the Islamist- the majority preferred to see the Islamist party banned and supported the regime on this initiative. This was due to three interconnected reasons. First of all, in the late 1980s suspicion was still rife that the Tunisian Islamists, despite their pro-democracy declarations, were essentially lying and would, if voted in, install an Iranianstyle theocracy instead. Second, the Algerian civil war of the 1990s played a crucial role in convincing the regime of the danger that Islamists posed and, quite significantly, it seemed to also convince many within the secular opposition camp that political Islam in all of its forms was dangerous and that therefore a secular dictatorship was preferable to a potentially Islamist one. Finally, in the 1989 legislative elections, the Islamists, running as independents came second, while the other opposition parties together received no more than three per cent of the votes cast. This electoral defeat encouraged some to ask for the exclusion of Islamists to avoid marginalisation in an electoral game dominated by the ruling Rassemblement Constitutionel Démocratique (RCD) and

\footnotetext{
${ }^{45}$ See the special report on Tunisian politics during the Ben Ali era by Youssef Ben Ismail, 'Dossier sur l'Extremisme Politique', El Moutawen, April 14, 2011. The two part special report in French is available at: http://elmouwaten.com/modules.php?name=News\&file=print\&sid=110.
} 
Al-Nahda. ${ }^{46}$ As indicated in the theory section, this highlights that for some opposition parties the authoritarian gatekeeper can under certain circumstances be perceived as an ally rather than a political rival.

The issue of the legalisation of Al-Nahda thus carried serious repercussions on the secular left, because parties that were otherwise ideologically close to one another were critically divided over this issue, further fragmenting the opposition camp. ${ }^{47}$ In this manner cross-party cooperation is rendered more difficult because the crucial issue of forming an alliance with the strongest opposition party, the Islamists, becomes a terrain of contestation.

To compound ideological differences, there were other strategic factors that fragmented the country's political opposition. There is no disputing the fact, for instance, that some of Ben Ali's social and political initiatives went in the direction that some opposition parties on the left and dissidents of the Bourguiba era appreciated, such as for example re-enforcing the progressive family code, the strengthening of public services in health and education, and insulating the country from the threat of Islamist violence. The seemingly impressive results of Ben Ali's socio-political reforms divided the secular left between those who supported these policies and those who criticised the authoritarian methods of policy-formation. The latter parties included, amongst others, the MDS, Ettadjdid and the PUP, all of which decided to work within the confines of the existing order, not simply because they derived material benefits, but also because of a genuine conviction that some of Ben Ali's most significant policy positions and achievements coincided with their own vision of what Tunisia should be doing. In order to continue down this road of progressive social reforms, these opposition parties thus sought it necessary to marginalise the Islamists; and keeping them out of power therefore became the mantra not only of the regime, but of many opposition parties and civil society organisations. For many within the women's movement, for instance, it was clear that the struggle against Islamism was more important than the struggle for genuine democracy and in this struggle the regime was an ally, although a thoroughly disliked one. ${ }^{48}$

Existent ideological and strategic divisions within the opposition were further compounded by petty personal rivalries amongst party leaders, which further diminished the prospects for crossparty cooperation during the Ben Ali era. Indeed, personality clashes and rivalries had not only contributed to the fragmentation of existing opposition parties, as highlighted above, but caused the

\footnotetext{
${ }^{46}$ K. Mohsen-Finan, 'Le Maghreb entre ouvertures nécessaires et autoritarismes possibles', Ramses Annual Report, 2006, pp. 111-126.

${ }^{47}$ N. Grimaud, 'La spécifité tunisienne en question', Politique Etrangère, 60 (1995), pp. 389-402.

${ }^{48}$ E. Dalmasso and F. Cavatorta, 'Reforming the Family Code in Tunisia and Morocco - The struggle between religion, globalisation and democracy’, Totalitarian Movements and Political Religions, 11 (2010), pp. 195-210.
} 
collapse of various electoral alliances that had been forged to improve the performance of the opposition in otherwise rigged and fraudulent parliamentary elections. In 2004, for instance, four opposition parties - the PUP, PSL, UDU and the Greens (PVP) - sought the formation of such an electoral alliance, under the banner of Rencontre Démocratique (Democratic Gathering), to contest the upcoming parliamentary poll. These parties had made the decision to work within the authoritarian rules of the game and intended to challenge Ben Ali by working from within the system. In order to increase their visibility and maximise their electoral gains, they set out to build a cross-party forum for discussion on potential shared principles. This forum would be turned into an electoral alliance, but this alliance was short-lived and collapsed 'amidst accusations that some party leaders tried to use the bloc to enhance their own standing rather than to build real unity. ${ }^{49}$ Initially, this coordinating effort revolved around discussions on joint initiatives on three themes: a) defending freedom of expression, association and press; b) institutional reforms including the electoral system and c) the issue of political prisoners and an amnesty for them. ${ }^{50}$ One of the points that emerged in the discussion was the parties' opposition to political Islam and if anything, it became clear that fighting what they called extremism was their most significant point of agreement. Thus, the decision to work within the authoritarian institutions and the anti-Islamist agenda both undermined the possibility of extending cross-party cooperation to political formations that did not believe in Ben Ali's democratic gradualism and did not support the marginalisation of Al-Nahda.

The initiative of Rencontre Démocratique took place at the same time when other opposition parties such as the PDP, the Congrés pour la République, the PCOT and Al-Nahda were calling for a boycott of the 2004 presidential and legislative elections to protest against the authoritarianism of president Ben Ali and against what they saw as his failure to follow through his rhetorical commitment to democracy. The partial boycott of the elections indicated that a number of opposition parties had come to the conclusion that the system could not be reformed and needed to be radically changed. Thus, the initiative of the Rencontre and the call for the boycott exposed the divisions of the opposition on the most crucial matters.

\section{The October 18 Collectif: Cross-ideological cooperation against the odds?}

After the 2004 elections, a more significant attempt at cross-party coordination was made by Tunisia's opposition with the formation of the so called October 18 Collectif, hereafter simply

\footnotetext{
${ }^{49}$ Alexander, Tunisia. Stability and Reform, p. 63.

${ }^{50}$ For a discussion of this see Martinez Fuentes, 'El Islam politico Tunecino', op .cit.
} 
referred to as the Collectif. This alliance, which was born in 2005 and comprised both legal and illegal parties, was forged with the aim of formulating a shared set of principles and reform demands around which to challenge the Ben Ali regime. On various levels the Collectif constituted a novelty in the Tunisian opposition political landscape, certainly compared to the preceding Rencontre Démocratique alliance. For one, it did not only comprise parties and movements of the secular opposition, such as the PCOT, the Nasserites, and a number of human rights groups, but also the Islamist Al-Nahda party. In contrast to Rencontre Démocratique, which was mainly composed of leftist parties, the Collectif thus cut across the entire ideological spectrum. Second, the Collectif was active for over five years, and this despite being composed of parties with vastly different ideological positions and being targeted by the repressive apparatus of the regime.

Three parties were at the forefront of its creation in 2005. These were the PDP, the Congrés pour la République and Al-Nahda. At the time, and in contrast to the other parties of the 'historical opposition' the PDP presented itself a genuine opposition party, thus functioning as magnet of leftists disillusioned with those parties on the left which had opted to support the regime as 'loyal opposition'. As mentioned earlier, Chebbi had founded the party in 1983, then known as the Rassemblement Socialiste pour le Progres (RSP). In 1988, when still operating under the banner of the RSP, the party was a signatory of the national pact and supported the early attempts made by Ben Ali to liberalise the political system inherited from Bourguiba. ${ }^{51}$ However, the party became sceptical of the process of gradual democratisation and increased its criticism of Ben Ali to an extent that by the early 2000s it was openly arguing that the authoritarian structures in place should be removed entirely. In order to gather more support in its struggle with the regime, the party was re-branded with the removal of all references to socialism and sought to broaden its support basis by becoming less doctrinaire in its programme. By the early 2000s, in fact, it had become absolutely clear to the PDP leadership that Ben Ali's promises of democratisation was all but an empty shell, with the 'war on terror' providing the regime ongoing cover for the harassment and repression of all political opponents. ${ }^{52}$ The necessity to build a wider opposition front, including the Islamists, in order to undermine the authoritarian stability of the regime and bring about democratic reforms thus became a key strategic objective of the PDP leadership.

\footnotetext{
${ }^{51}$ See a profile and history of the party at http://iphone.france24.com/fr/20110114-tunisie-mohammed-nejib-chebbipdp-opposition-ben-ali-gouvernement-union-nationale

52 V. Durac and F. Cavatorta 'Strengthening Authoritarian Rule through Democracy Promotion? Examining the Paradox of the US and EU Security Strategies. The Case of Tunisia,' British Journal of Middle Eastern Studies, 36 (2009), pp. 3-19.
} 
A second figure instrumental in the setting up of the Collectif was Marzouki, leader of the Congrés pour la République. A long-time human rights activist who had unsuccessfully attempted to run for president in 1994 and who had on various occasions challenged the regime only to be imprisoned and exiled, Marzouki had become convinced that the formation of a broad coalition of opposition forces committed to democratic principles and political pluralism was necessary to challenge the regime. Ben Ali's strategy of 'democratic gradualism' was no longer credible within many sectors of the Tunisian left and the anti-Islamist rhetoric also sounded hollow in the face of increasing repression, growing economic inequalities, and rampant corruption. Al-Nahda had for some time called on all opposition forces in Tunisia to participate in a national dialogue that would have the objective of setting out the principles upon which a new political system could be set up and the duo Chebbi/Marzouki took the risk of accepting such a dialogue.

The experience of working together on calls for the partial boycott of the 2004 parliamentary and presidential elections had demonstrated the need to transcend a priori ideological positions, as it was the first sign that cooperation across ideological lines was possible. It has been argued that cross-ideological cooperation in North Africa is particularly difficult because the ideological discourse of the parties of the left is very much influenced by the French notion of laicité, which makes it more difficult to accept any role for explicitly religious parties and their objective of formulating policies through religious principles. ${ }^{53}$ However, the trust that had been built between the PDP, the Congrés pour la République and al-Nahda in 2004 during the experience of the partial boycott made it possible to overcome ideological divisions. The Collectif attempted to go beyond the pragmatic need for unity against the common enemy and was designed as a vision of a future Tunisia, where shared democratic principles would regulate social and political relations. Thus, it demonstrated that divisions could also be overcome through intellectual exchanges around the most sensitive topics such as societal pluralism, democratic procedures and women's rights. In addition to this, the Collectif demonstrated that personalistic objectives could be set aside, with the leading members of the three parties engaging in meaningful discussions rather than grandstanding.

As mentioned earlier, the Collectif is remarkable not only in its cross-ideological composition but also long-term survival. Indeed, the five-year long engagement and dialogue between the parties comprising the October 18 Collectif that began in 2005 led to the publication in 2010 of a volume entitled 'Our way towards democracy', where democratic principles of

\footnotetext{
${ }^{53}$ Cavatorta, 'Divided they stand', op. cit.
} 
governance were affirmed to be the shared patrimony of all parties involved in the discussion. In an interview with the Financial Times, Ghannouchi argued that the Collectif was not simply 'a shortterm political coalition, but a social project for society, ${ }^{54}$ given that the parties had agreed on the fundamental pillars that should be put in place once authoritarianism was overthrown. These comprised political and social pluralism, as long as it is not expressed through violence, the rights of women and gender equality and freedom of conscience.

Thus, much like in other Arab countries, some opposition forces that had previously failed to cooperate in order to present a more serious challenge against the incumbent regime found crossparty and cross-ideological cooperation both necessary and rewarding in the sense that it contributed to dispel some of the mutual suspicions that previously existed between them. In so far as such diverse political and social movements were able to create a forum for engaging with each other under the same banner and with shared principles, the Collectif could be considered a success. As Al-Nahda leading member Abdel Salam stated 'dialogue between the Islamists and the secularists has shown that ideological differences can be surmounted"55, declaring the experience of the Collectf a success. The expressed enthusiasm of Al-Nahda is tempered, however, by the assessment of secular participants to the Collectif. Lotfi Hajji argued that 'the coalition does not represent a united front as there are many issues on which its members are divided', while Fathi Belhaj lists a number of ongoing difficulties that the Collectif faces, including the obstacle of ideological differences. ${ }^{56}$ These seemingly diverging attitudes illustrate the difficulty in assessing the success of this initiative. For some, the fact that cross-party and cross-ideological discussions took place is sufficient to argue that the initiative is a success, while for others the failure to agree on significant issues, such as for example the level of cooperation that should be had with foreign powers or the creation of an electoral alliance, indicate that the Collectif could only have a limited influence.

More specifically, there are four reasons as to why the experience of the Collectif should be evaluated more sombrely. First of all, repression played a crucial role, as all of the parties involved in the alliance found it extremely difficult to operate openly with most of their activities taking place in exile. ${ }^{57}$ Operating from abroad left the parties in exile open to the accusation of working for

\footnotetext{
54 The interview was published on-line on January 18, 2011 and is available at http://www.ft.com/cms/s/0/24d710a622ee-11e0-ad0b-00144feab49a.html\#axzz1Hq7pnwRv Accessed on January 19, 2011.

55 See the report 'What can we learn from Coalition-Building experiences?' published by the Arab Reform Initiative, February 2011, p. 4.

56 Ibid.

${ }^{57}$ L. Storm, 'The persistence of authoritarianism as a source of radicalization in North Africa', 85 (2009), pp. 997-1013.
} 
foreign powers and/or ideologies. These accusations, although coming from a less than credible regime, did undermine trust between those in exile and the ones active inside Tunisia. Second, other legalised opposition parties did not take part in this effort, undermining the very notion that the Collectif represented the whole of the opposition, as Ettajdid, the Greens (PVP), the Democratic Communists and other minor parties in addition to prominent members of women's rights and human rights groups did not wish to take part. ${ }^{58}$ Third, it took the member parties of the Collectif quite some time to agree on the basic principles of cooperation, with the final document published only five years after the alliance had been created. While the time was certainly necessary to iron out issues related to liberal rights and commitment to democratic procedures, and work out deeplyheld mutual suspicions, five years is a long time in politics. This continued focus on working through their differences left the parties unable to read the changing popular mood. Finally, the experience of the Collectif was an exercise in 'old politics' that many Tunisians had grown disillusioned with. Opposition political parties had been around for quite some time by this stage and did not seem to enjoy widespread credibility with the public. ${ }^{59}$ In fact, throughout the 2000 s, the very limited opposition politics permissible was largely taking place in the confines of some professional associations and through social networks that were not linked to parties. In addition, the personalities involved in the Collectif have a very long history and track record as politicians, which, again was not necessarily an advantage in a country where politicians did not enjoy great legitimacy. The fact that they had been around for long also undermined their stance with younger generations of Tunisians, as acknowledged by Rachid Ghannouchi himself. By the time they had managed to agree on common principles of action, the leaderless revolution had already moved on significantly, bypassing traditional political party structures. Ultimately, it should be highlighted that, despite its calls for boycotts of the 2004 and 2009 presidential elections and its productive discussions on the meaning of democracy that would apply across parties, the Collectif did not initiate the uprising, failed to sustain it unequivocally (the PDP's leadership did not for instance call for Ben Ali's departure) and was eventually taken over by events on the ground, which it had not predicted. As made clear by Kausch, 'a great deal of disunity' ${ }^{60}$ has always characterised opposition party politics in Tunisia and when finally cross-ideological cooperation became a reality, the parties involved were overtaken by political events on Tunisia's streets.

\footnotetext{
${ }^{58}$ Martinez Fuentes, 'El Islam Politico Tunecino', op. cit.

${ }^{59}$ M. Willis, 'Political Parties in the Maghrib: the Illusion of Significance?', Journal of North African Studies, 7 (2002), pp. 1-22.

${ }^{60}$ K. Kausch, 'Tunisia: The Life of Others', FRIDE Working papers, No. 85, June (2009), p. 11.
} 
Finally and probably more importantly, old divisions are emerging again in preparation of the October 2011 elections for the Constitutional Assembly, with the traditional suspicions of the democratic commitment of the Islamists resurfacing among leftists, including Chebbi. The state's laicité has become a central issue of current political debates in Tunisia, as Al-Nahda is proving to be the better equipped party to run the election campaign, particularly at a time when many Tunisians seem to desire some sort of role of religion in public policy. ${ }^{61}$ More than ninety political parties have been legalised in Tunisia since the departure of Ben Ali, in recognition that competition between a plurality of parties still provides the main tool for ensuring democratic representation and accountability. However, the divisions of the past are still haunting the present transition and appear to affect the way in which party politics is developing in post-revolutionary Tunisia with disunity and fragmentation being blamed for the inability to offer a clear path out of the chaos that the departure of Ben Ali has left. This in turn has led to disaffection towards party politics on the part of many ordinary citizens and this constitutes a potentially significant problem for the process of regime change. ${ }^{62}$

\section{Conclusion}

It would be presumptuous to state that there are already clear lessons to be learned at this stage from the Tunisian uprising and it would be out of place to attempt to already explain what circumstances led to the uprising and the departure of Ben Ali on January 14, 2011. However, an examination of opposition politics in Tunisia during the Ben Ali's regime can partly explain why opposition parties not only failed to predict and spark the uprising, but also why in its aftermath they seem to be struggling to gain legitimacy. The national pact offered by Ben Ali in 1988 to parties that had been repressed during the previous regimes seemed to offer the potential for a genuine involvement of opposition parties in the construction of a new democratic Tunisia. However, Ben Ali had other plans and quickly hijacked the process of liberalisation he had initiated and increasingly turned Tunisia into a police state. As part of his strategy, Ben Ali began to implement divide and conquer policies aimed at taming the opposition. This was possible and ultimately successful because of three factors, namely (1) ideological rivalries, including the left's mistrust of the Islamists and intraleft disagreements, (2) strategic differences as to the position to take vis à vis the regime and (3)

\footnotetext{
${ }^{61}$ F. Dahmani, 'Tunisie, la laicité en danger', La Jeune Afrique No., 2623/2634 (17-30 April, 2011), pp. 36-37. According to a March 2011 poll, 48 per cent of Tunisians stated that they would strongly or somewhat prefer politics to be based on religion. See IRI, Williams and Associates, Salem, Massachusetts, www.WilliamsPolls.com.

${ }^{62}$ See a special report on political parties in post-revolutionary Tunisia by Abdelaziz Barrouhi in La Jeune Afrique, No. 2627, May 1-21, 2011, pp. 42-47.
} 
personal disputes. Divide and conquer strategies have been common currency in the Arab world and the weakness of the opposition, demonstrated in its inability to build lasting and potent reform coalitions, finds confirmation in the Tunisian case. This is despite a growing literature stressing the relevance of cross-party collaboration within the opposition and more specifically cross-ideological cooperation.

For the most strategic and thoughtful of party leaders, cross-ideological co-operation became the strategy to pursue, if a challenge to the regime was to be successful. Chebbi of the PDP, Ghannouchi of Al-Nahda and Marzouki of the Congres pour la Republique created the Collectif alliance in 2005, with the intent of opposing the regime and providing a democratic blueprint for Tunisia. As positively as it does compare to prior cooperation efforts or more appropriately the lack thereof, even the Collectif can in the end not claim to have been successful, as it was also plagued by significant internal disagreements that prevented it from emerging as a strong and coherent opposition front, capable of challenging the authoritarian foundations of the Ben Ali regime. Nor was the Collectif significantly involved in the 2011 uprising which brought down the Ben Ali regime, and was driven by a new set political actors drawn together by the informality of social networks that emerged outside the formal opposition party structures. The experience of the Collectif did not survive the post Ben Ali era, given that the parties involved are finding themselves increasingly at odds as to how to best ensure a smooth transition in Tunisia, and with Chebbi already positioning himself as an anti-Islamist candidate reneging on the experience of the alliance. While this might be understandable in the context of democratic politics, Tunisia is not yet there and some form of a united front would be a useful to reach a broad-based consensus on key reform legislation, including a new constitution, and to send a powerful message of unity of purpose to the population. It seems that even in euphoric times, old habits die hard.

However, there is one lesson to be learned from the Tunisian experience that could have more general applicability in other transitional contexts in the Arab world. The weakness of political parties is a widespread phenomenon in the region and other forms of politics seem to be both more popular and legitimate, particularly among young people, who are unwilling to accept the formal constraints of parties often perceived as inefficient and corrupt as the ruling elite, but are eager for political participation. This represents a potential obstacle for democratic change because democratic governance still rests on representation through political parties, as they are the only entities with the ability to guarantee the aggregation of individual values and preferences. However, the poor track record of cross-party cooperation during the Ben Ali period and the coordination 
failures that have plagued opposition parties indicate that they might not in fact be capable of playing the role of aggregators of preferences, with ordinary citizens growing increasingly frustrated at the way in which political parties seem unable to abandon their narrow interests. Thus, examining the failures of opposition parties in Tunisia to sustain a common front against the dictatorship of Ben Ali can contribute to explaining the fraught nature of the relations that exist in post-Ben Ali Tunisia between the political parties. The case of Tunisia highlights the challenges parties face in creating and sustaining effective coordination under severe authoritarian constraints and indicates how the legacy of coordination failures can prevent the building up of new institutions when the authoritarian gatekeeper is no longer present.

\section{References:}

Abdelrahman, M. (2009) 'With the Islamsits? - Sometimes. With the State? - Never! Cooperation between the Left and Islamists in Egypt,'British Journal of Middle Eastern Studies 36/1, pp. 37-54.

Albrecht, H. (2010) 'Introduction - Contentious Politics, Political Opposition, and Authoritarianism,' in H. Albrecht (ed.) Contentious politics in the Middle East: Political Opposition under Authoritarianism (Florida: Florida University Press).

Albrecht, H. (2005) 'How Can Opposition Support Authoritarianism? Lessons from Egypt,' Democratization 12/3, pp. 378-397.

Alexander, C. (2010) Tunisia. Stability and Reform in the Modern Maghreb (London: Routledge).

Allal, A. (2010) 'Ici ca ne bouge pas ca n'avance pas'. Les mobilisations protestataires dans la region minière de Gafsa en 2008,' in M. Catusse, B. Destremau and E. Verdier (eds.) L'Etat face aux débordements du social au Maghreb (Paris, IREMAM/Khartala).

Allani, A. (2009) 'The Islamists in Tunisia between Confrontation and Participation: 1980-2008,' Journal of North African Studies 14/2, pp. 257-272.

Anderson, L. (2006) 'Searching where the Lights Shines: Studying Democratization in the Middle East,' Annual Review of Political Science 9, pp. 189-214

Anderson, L. (1991) 'Political Pacts, Liberalism and Democracy: the Tunisian National Pact of 1988,' Government and Opposition 26/2, pp. 244-260.

Beau, N. and J.-P. Tuquoi (1999) Notre Ami Ben Ali (Paris: La Découverte).

Basly, R. (2011) 'The Future of al-Nahda in Tunisia,' Arab Reform Bulletin, April 20. Available at: http://www.carnegieendowment.org/arb/?fa=show\&article=43675 (last access: April 27, 2011). 
Bellin, E. (2004) 'The Robustness of Authoritarianism in the Middle East,' Comparative Politics, 36/2, pp. 139-158.

Ben Abdallah El Alaoui, H. (2011) ‘Tunisie, les éclaireurs,' Le Monde Diplomatique 683, February.

Ben Yahmed, B. (2011) 'Jours de victoire...,' La Jeune Afrique 2610, 16-22 January.

Browers, M. (2009) Political Ideology in the Arab World (Cambridge, Cambridge University Press).

Browers, M. (2007) 'Origins and Architects of Yemen's Joint Meeting Press,' International Journal of Middle East Studies 39 /4, pp. 565-586.

Brumberg, D. (2002) 'The Trap of Liberalized Autocracy,' Journal of Democracy 13/4 pp. 56-68.

Cavatorta, F. (2009) 'Divided they Stand, Divided they Fail. Opposition Politics in Morocco,' Democratization 16/2, pp. 137-156.

Cavatorta, F. (2007) 'More than Repression; Strategies of Regime Survival: The Significance of Divide et Impera in Morocco,' Journal of Contemporary African Studies 25/2, pp.187-203.

Chomiak, L. and J. Entelis. 'Contesting Order in Tunisia: The Crafting of Political Identity,' in E. Lust and F. Cavatorta (eds.) State-Society Relations under Authoritarian Constraints (London: Routledge, forthcoming).

Clark, J. (2010) 'Threats, Structures and Resources,' Comparative Politics 43/3, pp. 101-120.

Clark, J. (2006) 'The Conditions of Islamist Moderation: Unpacking Cross-Ideological Cooperation in Jordan,' International Journal of Middle East Studies 38/4, pp. 539-560.

Dahmani, F. (2011) 'Tunisie, la laïcité en danger,' La Jeune Afrique 2623/2634, 17-30 April, pp. 36-37.

Dalmasso, E. and F. Cavatorta (2012) 'The Emerging Power of Civil Society? The Human Rights Doctrine,' in B. Maddy-Weitzman and Daniel Zisenwine (eds.) Contemporary Morocco: State, Politics and Society under Mohammed VI, (Routledge, London, forthcoming).

Dalmasso, E. and F. Cavatorta (2010) 'Reforming the Family Code in Tunisia and Morocco - The Struggle between Religion, Globalisation and Democracy,' Totalitarian Movements and Political Religions 11/2, pp. 195-210.

Durac, V. and F. Cavatorta (2009) 'Strengthening Authoritarian Rule through Democracy Promotion? Examining the Paradox of the US and EU Security Strategies: The case of Tunisia,' British Journal of Middle Eastern Studies 36/1, pp. 3-19.

Friedman, G. (2011) 'Egypt: the distance between enthusiasm and reality', Stratford Weekly, February 13. Available at: http://www.stratfor.com/weekly/20110213-egypt-distance-betweenenthusiasm-and-reality (last access: February 13, 2011). 
Gobe, E. (2010) 'The Tunisian Bar to the Test of Authoritarianism: Professional and Political Movements in Ben Ali's Tunisia (1990-2007),' Journal of North African Studies 15/3, pp. 333-347.

Grimaud, N. (1995) 'La spécifité tunisienne en question,’ Politique Etrangère 60/2, pp. 389-402.

Haugbølle R. and F. Cavatorta (2011) 'Vive la grande famille des media tunisiens! Media Reform and Authoritarian Resilience in Tunisia,' Journal of North African Studies, forthcoming.

Heydemann, S (2007) 'Upgrading Authoritarianism in the Arab World,' The Brookings Institution, Analysis Paper 13, pp. 1-37.

Hibou, B. (2006) La Force de l'Obéissance (Paris : La Découverte).

Kausch, K. (2009) 'Tunisia: The Life of Others,' FRIDE Working Papers 85.

Kraetzschmar, H. (2010) 'Opposition Cooperation in Electoral Autocracies: The United National Front for Change in Egypt's 2005 Parliamentary Elections,' in H. Albrecht (ed.) Contentious politics in the Middle East. Political Opposition under Authoritarianism, (Florida: Florida University Press).

Lust, E. (2006) 'Elections under Authoritarianism: Preliminary Lessons from Jordan,' Democratization 13/ 3, pp. 456-47.

Martinez Fuentes, G. (2011) 'El Islam politico Tunecino. Conflicto y coopearcion electoral en los comicios presidenciales de 2004 y 2009,' Revista CIDOB d'Afers Internacionals 93/94, pp. 89-109.

Martinez Fuentes, G. (2010) 'Divisive electoral policies within authoritarian elections: the Tunisian casuistry (1989-2009),' Journal of North African Studies 15/4, pp. 521-534.

Mohsen-Finan, K. (2006) 'Le Maghreb entre ouvertures nécessaires et autoritarismes possibles,' Ramses Annual Report, pp. 111-126.

Murphy, E (1999) Economic and Political Change in Tunisia. From Bourguiba to Ben Ali (London: Palgrave Macmillan).

Ottaway, M. (2011) 'The Presidents left, the regimes are still there,' Carnegie Endowment, February 14. Available at: http://carnegieendowment.org/publications/?fa $=42627$ (lat access: February 14, 2011).

Penner Angrist, M. 'Parties, Parliament and Political Dissent in Tunisia,' Journal of North African Studies 4/4, pp. 89-104.

Perkins, K. (2004) A History of Modern Tunisia (Cambridge: Cambridge University Press).

Sadiki, L. (1997) 'Towards Arab liberal democracy: From Democracy of the Bread to Democracy of the Vote,' Third World Quarterly 18/1, pp. 127-148. 
Schwedler, J. (2006) Faith in Moderation (Cambridge: Cambridge University Press).

Sfeir, A. (2006) Tunisie Terre de Paradoxes (Paris: Editions de l'Archipel).

Storm, L. (2009) 'The Persistence of Authoritarianism as a Source of Radicalization in North Africa,' International Affairs 85/5, pp. 997-1013.

Valbjørn, M. and A. Bank (2010) 'Examining the Post in Post-Democratization: The Future of Middle Eastern Political Rule through the Lenses of the Past,' Middle East Critique 19/3, pp. 183200.

Van de Walle, N. (2006) 'Tipping Games: When Do Opposition Parties Coalesce?,' in A. Schedler (ed.) Electoral Authoritarianism: The Dynamics of Unfree Competition (Boulder: Lynne Rienner).

Willis, M. (2002) 'Political Parties in the Maghrib: the Illusion of Significance?,' Journal of North African Studies 7/2, pp. 1-22. 